\title{
EVOLUTION OF CILIARY FEEDING IN THE PROSOBRANCHIA, WITH AN ACCOUNT OF FEEDING IN CAPULUS UNGARICUS
}

\author{
By C. M. Yonge, D.Sc. \\ University of Bristol
}

(Text-figs. I-6)

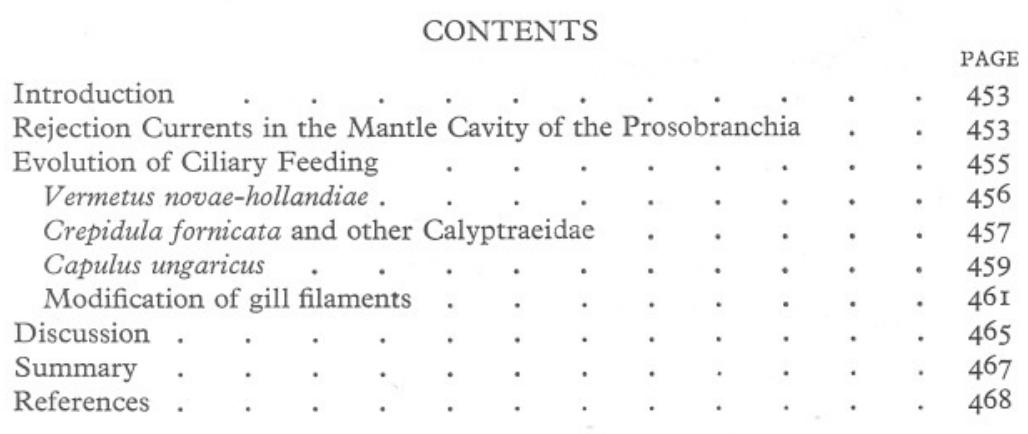

\section{INTRODUCTION}

Ciliary feeding, of such widespread occurrence in the Lamellibranchia, is confined in the Gastropoda to a few scattered groups. In freshwater Pulmonata, such as Limnaea, cilia on the foot assist in feeding when the animal is creeping suspended from the surface film (Brockmeier, I898). Thecosomatous Pteropoda feed exclusively by the aid of cilia on the unpaired middle lobe and the paired side lobes of the foot, and an evolutionary seriesCavolinia-Cymbulia-Gleba-can be traced in which there is a progressive elaboration in the perfection of this mechanism and an accompanying reduction in the buccal mass and associated structures handed down from carnivorous ancestors (Yonge, I926). Only in the few prosobranchs which have acquired ciliary feeding mechanisms do these represent a modification of the ctenidia as in the Lamellibranchia. They also, as it is the aim of this paper to show, represent a modification of the rejection currents present in the mantle cavity of typical prosobranchs.

\section{Rejection Currents in the Mantle Cavity of the Prosobranchia}

In typical Prosobranchia a respiratory current, created by the beating of the lateral cilia on the gill filaments, is drawn into the mantle cavity by way of the inhalent opening (frequently prolonged into a siphon, e.g. in Buccinum) on 
the left side of the head and, after passing between the gill filaments where respiration takes place, passes out by the exhalent opening on the right side. Any sediment present in the water must inevitably be drawn in with this current and, if the gills and other important organs in the mantle cavity are not to be smothered by it, it is essential that mechanisms should exist for its rapid and efficient removal. In a recent paper on Aporrhais (Yonge, I937)

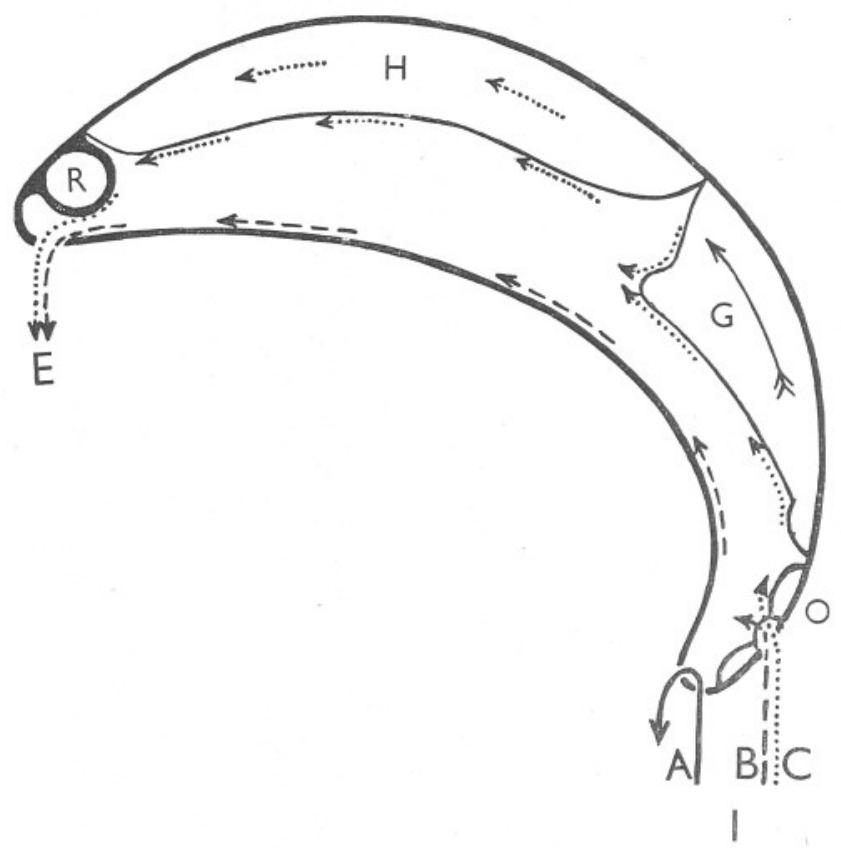

Fig. I. Semi-diagrammatic representation of course of the ciliary currents within the mantle cavity of a typical pectinibranch prosobranch. A, B, C, three sets of rejection currents represented by unbroken, broken and dotted arrows respectively; E, exhalent current (downward arrows representing outward current at right angles to plane of figure); I, inhalent current (upward arrows representing inward current as before); G, gill filament (feathered arrow representing respiratory current created by lateral cilia); H, leaflet of hypobranchial gland; o, osphradium (with paired lateral plates as in Buccinum); $\mathrm{R}$, rectum.

it was shown that disposal of suspended matter is brought about by the following three well-defined sets of ciliary currents:

A. Cilia on the margin of the inhalent region carry the largest and heaviest particles, which tend to settle almost at once, directly to the exterior, i.e. by way of the inhalent opening.

B. Cilia on the floor of the mantle cavity carry medium-sized particles, which settle farther within the cavity, across to the right side where they are caught in forwardly directed currents and conveyed to the exhalent opening. 
C. Frontal cilia on the gills and cilia on the folded surface of the hypobranchial gland carry the lightest particles, which still remain in suspension when the water passes between the gill filaments, across the roof of the mantle cavity. These minute particles become entangled in the mucus produced by the hypobranchial gland-hence the size and importance of this gland-and, so consolidated, are carried to the right side where they are conveyed forward and out together with the medium-sized particles and the faeces.

The relation of these three sets of currents to one another is shown diagrammatically in Fig. I. It will be noted that the osphradium (o) represents the line of division between currents B and C.

The same general arrangement of rejection currents has been found in such typical pectinibranch Prosobranchia as Littorina littorea, L. rudis, Nucella (Purpura) lapillus, Nassarius (Nassa) reticulatus and Buccinum undatum by Mr G. C. E. B. Hulbert while working under the direction of the author. The only organ in the mantle cavity which shows marked variation in form is the osphradium. It is suggested, on biological grounds, that the function of the osphradium is to determine the amount of sediment which enters the mantle cavity (Hulbert \& Yonge, 1937). This varies widely according to the habitat of the animal.

\section{Evolution of Cillary Feeding}

A consideration of the above facts has indicated the possible mode of origin of the ciliary feeding mechanisms which have been described in Crepidula and Calyptraea (Orton, I9I2, I914), Vermetus novae-hollandiae (Yonge, I932), and briefly noted in Capulus ungaricus by Orton (I9I2). Further observations were made by the author on the last-named during a visit to the Bergens Museum Biological Station at Herdla in 1936, and also on specimens obtained from the marine laboratories at Plymouth and Millport. The author wishes to acknowledge his indebtedness to Prof. A. Brinkmann, Director of the Bergen Station, and also, for financial assistance, to the Colston Research Society, Bristol.

All of these animals are specialized herbivores. This fact is established by the universal presence in them of a crystalline style, characteristic (Yonge, I932) of herbivorous Gastropoda "which feed by ciliary mechanisms, or by the slow but almost continuous action of a radula". Ciliary feeding representing a further specialization associated with a sedentary mode of life, it follows that we must consider the ancestors of animals feeding in this manner to have been primitive herbivorous prosobranchs, possessing styles, but probably feeding by means of a radula and jaws. The single pectinibranch gill of such a form would be concerned solely with its primitive function of respiration and ciliary currents in the mantle cavity only with rejection of sediment.

Such primitive herbivorous prosobranchs appear to have evolved in various directions. One line of evolution is represented by animals such as Pterocera and other Strombidae (Yonge, 1932): they possess a proboscis and use the 
jaws to crop fine algae which are broken down in the stomach by a cellulase. The radula shows little sign of wear "evidently acting as a conveyor belt" (Peile, 1937). Another line of evolution is represented by Aporrhais (Yonge, I937), which burrows in mud and collects detritus of plant origin with the aid of an extensile proboscis possessing grasping jaws and radula. Other lines are represented by groups-not necessarily closely related to one anotherwhich have lost the power of movement, either as a result of cementation to the substratum as in the Vermetidae, or effectively as in the Calyptraeidae and Capulidae. In these families, as in the Lamellibranchia, the gills and the ciliary currents in the mantle cavity have become modified to enable the animals to collect fine particles, chiefly phytoplankton, from the surrounding water.

\section{Vermetus novae-hollandiae.}

The simplest case would appear to be that of Vermetus novae-hollandiae (Yonge, I932). This large species lives, cemented to dead coral rock, on the exposed outer faces of Indo-Pacific coral reefs. Unlike the smaller V. gigas which lives in still waters in the Mediterranean and, as recently conclusively demonstrated by Boettger (I930), collects plankton by means of long

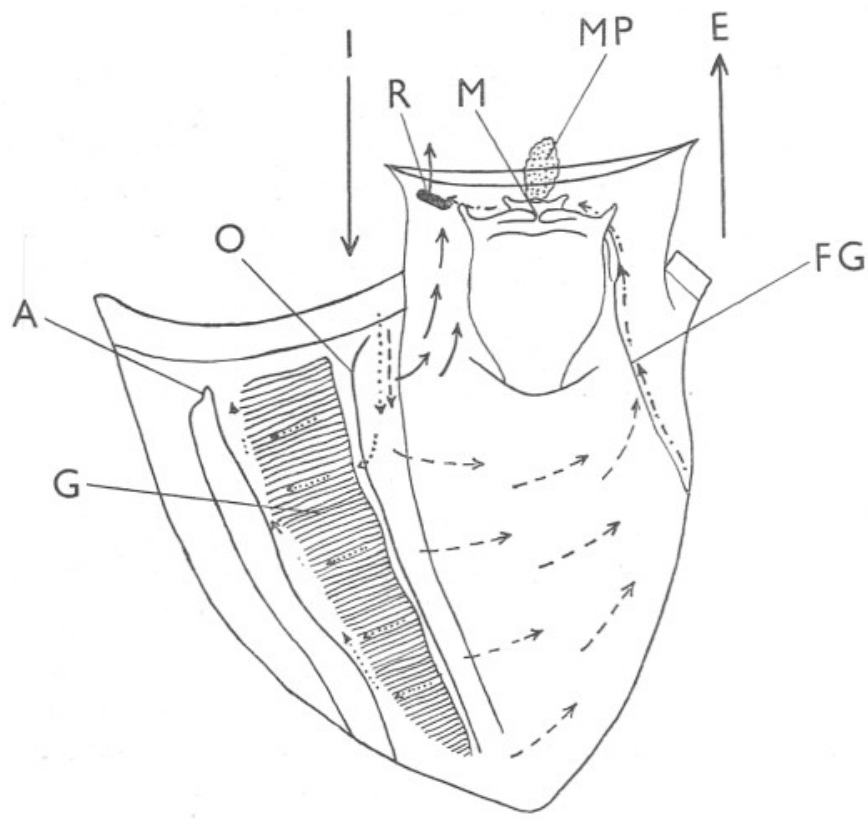

Fig. 2. Vermetus novae-hollandiae, mantle cavity opened along right side, seen from above. $\times I \frac{1}{2}$. A, anus; E, exhalent current; FG, food groove; G, gill; I, inhalent current; $M$, mouth; MP, mucus from pedal gland; $\mathrm{O}$, osphradium; $\mathrm{R}$, position where large particles collected prior to rejection by action of current A. Various currents represented by same type of arrows as in Fig. I. (Figure modified after Yonge, 1932.) 
mucous threads extruded from the pedal gland, $V$. novae-hollandiae is a ciliary feeder. As shown in Fig. 2, heavy material is accumulated on the left side of the head and then rejected; this represents current A. Medium-sized material is carried across the floor of the mantle cavity in current B, where it passes into a food groove which carries it to the mouth. Finely divided material-which will include phytoplankton on which the animal chiefly feeds-is carried by frontal cilia on the gill filaments to the free edge of the gill where other cilia carry it anteriorly. In life this free edge is in close apposition to the food grove (FG) on the right side of the mantle cavity. This current clearly represents a modification of current C. It should further be noted that there is no hypobranchial gland. The increased size of the gillthe result of its added function as a collector of food-leaves no space for this organ, which is in any case unnecessary because material is no longer passed completely across the roof of the mantle cavity but carried at right angles, anteriorly, along the free edge of the gill.

Food which enters the food groove from either current B or C is carried round the right-hand side of the head to the mouth (M). As food streams approach, the small introvert is extruded over the opening of the pedal gland, the mouth opens and the exposed radula seizes the food which has been mixed with mucus from the pedal gland (MP). Any excess of material passes farther to the left and joins the material rejected by current A. The secretion of the pedal gland, no longer required to provide lubrication for movement, is thus concerned with the consolidation of food particles but not with its direct capture as in $V$. gigas.

Crepidula fornicata and other Calyptraeidae.

In Crepidula fornicata (Orton, I9I2, I9I4) the elaboration of the ciliary feeding mechanisms has been carried several stages farther. The mantle cavity is of relatively enormous size, extending over the entire visceral mass and also over the elongated "neck" region. This provides for the accommodation of the gill, which is many times larger than that of typical prosobranchs of the same body size (it is also relatively larger than that of V.novae-hollandiae, though not to the same extent). This increase in the gill is due to the greater current needed for feeding and the increased surface for food collection. The modifications of the individual filaments will be discussed later. The osphradium (Fig. 3, o) is reduced to a small area at the anterior end of the gill, but an endostyle (EN) extends along the entire base of the gill. ${ }^{\star}$ This structure, described in detail by Orton (I9I2, I9I4), is confined to the Calyptraeidae (Crepidula and Calyptraea) and represents a special adaptation for ciliary feeding in these animals, producing mucus which is carried on to the ventral, frontal surface of the gill filaments.

\footnotetext{
* In V. novae-hollandiae an elongated osphradium (Fig. 2, 0) runs along the base of the gill, not an endostyle as described in my paper (Yonge, I932). I am glad to have an opportunity of correcting this error. There are always abundant mucous glands in this region.
} 
Food reaches the mouth by one of two routes. Large particles are carried direct into a food pouch (FP) in the mantle edge, which is situated, in life, just anterior to the mouth. They are there worked up into a pellet with mucus and passed to the mouth. If food is not required or excess of material is present, it is carried out by a current which runs parallel to and slightly anterior to the food pouch. It is clear that this feeding current represents a modification of rejection current A. Medium and fine particles are carried

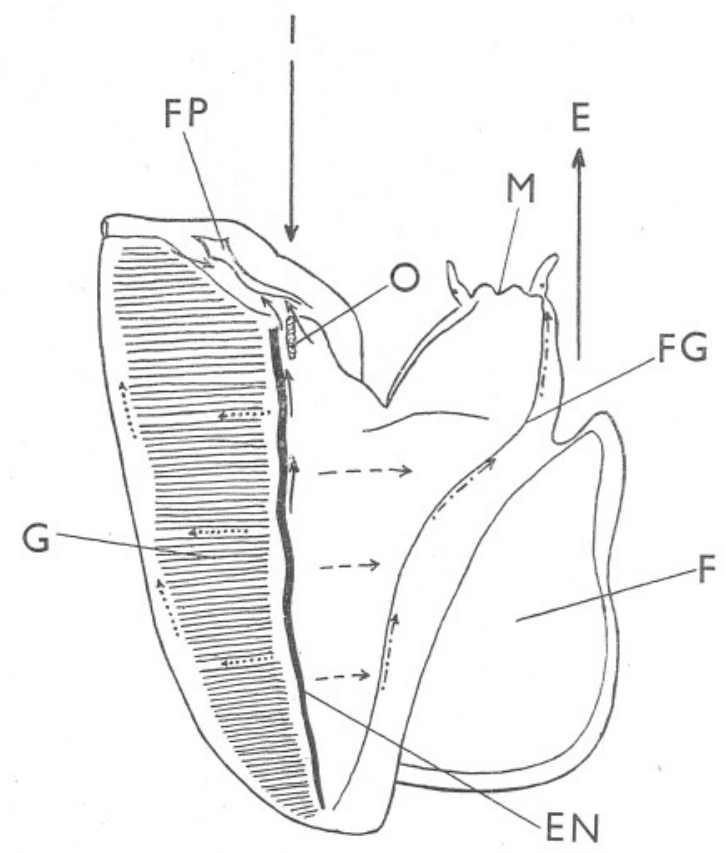

Fig. 3. Crepidula fornicata, mantle cavity opened along right side, seen from above. $\times \mathrm{I}_{\frac{1}{2}}$. EN, endostyle; F, foot; FP, food pouch. Other lettering as in Fig. 2. (Figure modified after Orton, 1914.)

over the floor of the mantle cavity in current B, but chiefly, entangled in mucus secreted by the endostyle, by way of the frontal cilia of the gill filaments (i.e. current $\mathrm{C}$ ). By both routes particles pass into the food groove ( $\mathrm{FG}$ ) and are carried forward by the combined action of its cilia and those on the tips of the gill filaments. The food particles are here worked up into pellets with mucus and are passed from time to time to the mouth $(M)$. There they are grasped and passed into the buccal cavity by the radula and retained there by the jaws prior to swallowing. Peile (1937) has remarked on the absence of wear in the teeth of the radula in both Crepidula fornicata and Calyptraea chinensis. There is no trace of a hypobranchial gland.

Orton found essentially the same conditions in Calyptraea and they almost 
certainly prevail throughout the Calyptraeidae. Kleinsteuber (I9I3), in a comparison of the genera of this family, has pointed out that in Calyptraea, Crepidula and fanacus the length of the gill filaments is about one-half, in Trochita some three-quarters and in Crucibulum twelve-thirteenths the width of the body.

Capulus ungaricus.

The only existing account of feeding in this very interesting species being confined to a brief statement by Orton (I9I2), a more detailed account would

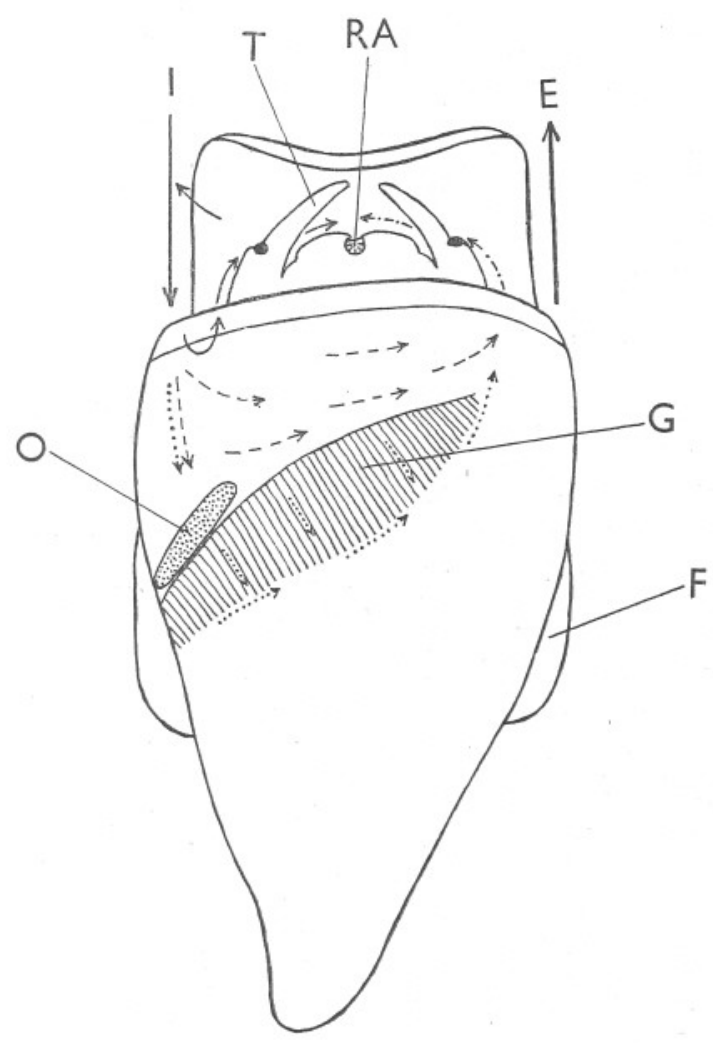

Fig. 4. Capulus ungaricus, animal seen from above after removal of shell; organs and currents in mantle cavity shown. $\times 3$. RA, radula; $\mathrm{T}$, tentacle. Other lettering as before.

appear to be well justified, apart from its importance in connexion with the general subject-matter of this paper. The animal has very limited powers of movement and is often found attached to the free edge of the valves of Lamellibranchia. The appearance of the animal from the dorsal aspect after the limpetlike shell has been removed is shown in Fig. 4, which also indicates the 
position, within the mantle cavity, of the gills (G) and osphradium (O). The head with the stout tentacles $(\mathrm{T})$ projects a little beyond the mantle edge. The position of the mouth and contained radula (RA) is shown but not that of the remarkable grooved proboscis. The proboscis appears in Fig. 5 (P), drawn after it and the foot had been extended anteriorly. It is formed of the prolonged lips and extends downwards, the tip lying on the flat, upper surface of the anterior prolongation of the foot. The gill is very large and extends obliquely across the roof of the mantle cavity, instead of along the left side

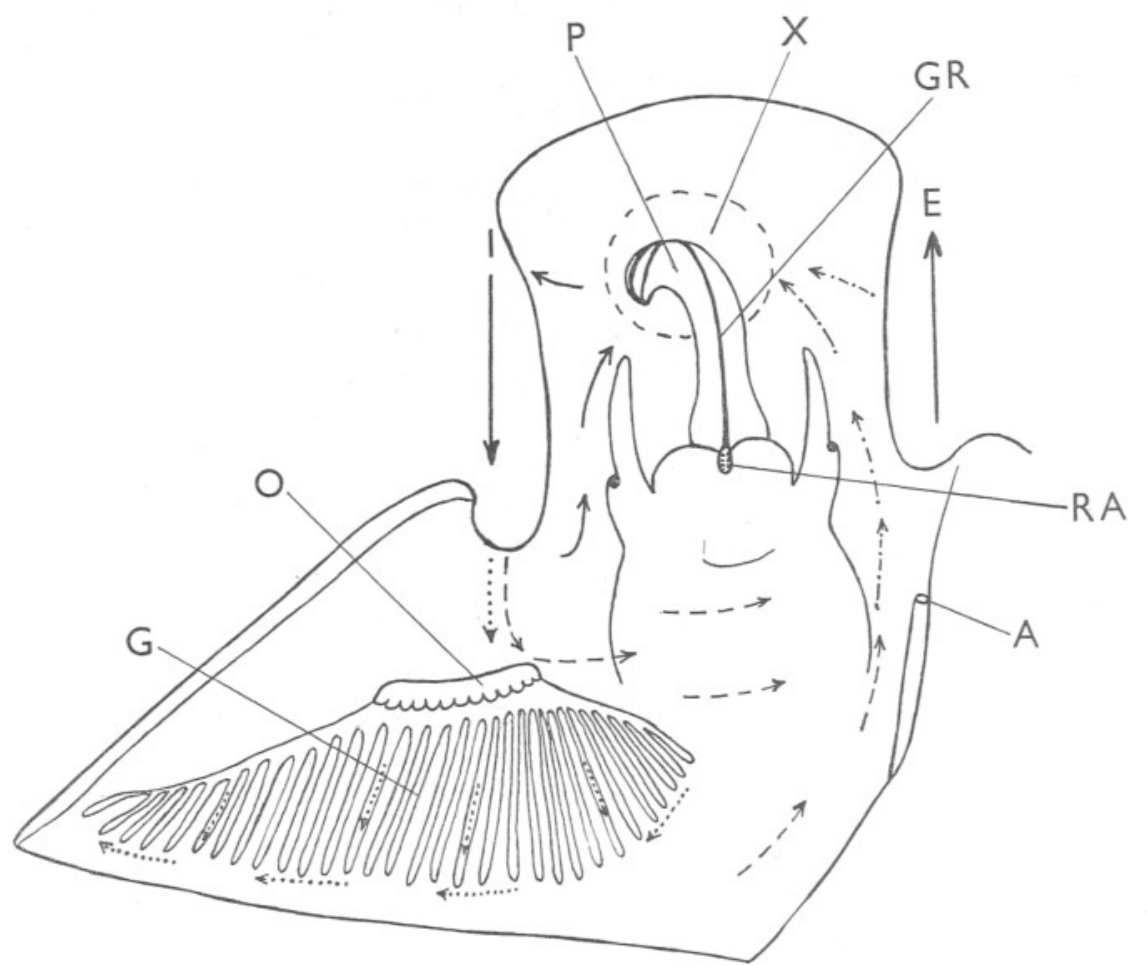

Fig. 5. Capulus ungaricus, mantle cavity opened along right side, seen from above. $\times 3$. $\mathrm{GR}$, groove along proboscis; $\mathrm{P}$, proboscis; $\mathrm{x}$, region of propodium, below proboscis, where food material collects. Other lettering as before.

as in a typical prosobranch or in the other ciliary feeding species. This would appear to be a direct consequence of its large size; it could not be accommodated in the restricted mantle cavity were it not so disposed. There is a conspicuous osphradium (Figs. 4 and 5, 0) but no hypobranchial gland.

The powerful inhalent current (I), created by the lateral cilia on the gill filaments, enters the mantle cavity on the left side and impinges almost at right angles on the obliquely situated osphradium. The heaviest suspended 
material does not reach this organ, but is caught in current A and carried round the upper surface of the anterior prolongation of the foot to the region of the tip of the proboscis. The osphradium represents the division between currents $\mathrm{B}$ and $\mathrm{C}$, the former carrying medium-sized particles over the floor of the mantle cavity and the latter consisting of currents on the gills. These last currents are produced by frontal cilia which carry fine particles to the tips of the filaments; here particles come under the influence of currents caused by conspicuously large cilia and are conducted, embedded usually in mucous strings, along the tips of the filaments in an obliquely anterior direction towards the exhalent opening. There are also abfrontal cilia, smaller than those on the frontal surface, which carry particles to the tips of the filaments.

Material in currents B and C unites in a common stream near the exhalent opening and passes anteriorly round and beneath the head to join material from current $A$ on the upper surface of the propodium (in the region marked $\mathrm{X}$ in Fig. 5). Material here collects in mucus-laden masses-sections reveal abundant mucous glands in and below the epidermis in this region-and on these the animal feeds by means of the proboscis. Food passes up the groove in the proboscis (GP) by means of ciliary, possibly aided by muscular, action; the radula appears to have an essentially conveying function. Peile (I937) states that in "Capulus ungaricus the teeth are slightly blunted in a few of the front rows".

Orton (I9I2) states that the proboscis "appears to be held along the right side of the animal to collect the food-particles from the tips of the gills when the animal is feeding". Nothing corresponding to this was observed in any of the three specimens examined. Orton, however, admits that he had no opportunity of investigating Capulus fully.

Unlike the Calyptraeidae further evolution within the Capulidae has been towards parasitism. Certain species of Capulus have been described as parasites, but this may be due to a misinterpretation of the true function of the proboscis; there is, however, no question as to the ecto-parasitic habits of all species of the allied genus Thyca. Here the animal is attached throughout adult life to the body of echinoderms. The foot is correspondingly reduced; the radula is lost, but the proboscis is elongated and penetrates deep into the body of the host, apparently sucking in the coelomic fluid (see Schepman \& Nierstrasz, 1909; Koehler \& Vaney, 1912). The species of the allied but completely sedentary family Hipponycidae probably feed in a similar manner to Capulus.

Modification of gill filaments.

The elaboration of ciliary feeding mechanisms in these Prosobranchia has involved, above all else, modifications of the gill filaments. The nature of these modifications can best be discussed by reference to Fig. 6, in which appear lateral views of complete filaments and also transverse sections near the base, from the gills of the three species already discussed. Similar figures 
of Buccinum undatum, as an example of a pectinibranch prosobranch in which the gills are exclusively concerned with their primitive function of respiration, are also given. The filaments of Littorina littorea and of Aporrhais pespelecani, which were also examined, do not differ essentially from those of Buccinum. Except for Vermetus, the drawings of the complete filaments were all made from living tissue.

The first point of interest is the progressive increase in the length of the filaments in comparison to width at the base. In Buccinum (Fig. 6 A), and similar Prosobranchia, the filaments are roughly triangular with the base and height about equal; the other extreme is represented by Crepidula (Fig. 6 D), where the filament is narrow throughout and greatly elongated. The ratio of height to maximum width is in Buccinum (A) I: I, in Vermetus (B) $2.75: \mathrm{I}$, in Capulus (C) 3:I and in Crepidula (D) 26: I. In Vermetus the figures given are based on measurements of preserved filaments which, as indicated by the transverse section, contract considerably in width; they are thus not strictly comparable with the others and the ratio should certainly be lower and so nearer to conditions in Buccinum.

In the general distribution of the main tracts of cilia, frontals $(f)$, laterals $(l)$ and abfrontals $(a)$-the last being always somewhat shorter and more sparse than the frontals-and in the presence of the internal chitinous supporting rods $(c)$, the various filaments do not differ fundamentally. In all the frontals and abfrontals beat towards the tips of the filaments and the laterals transversely. In Buccinum the particles carried to the tip are then carried over farther to the right (when the gill is in situ) and so on to the hypobranchial gland as shown in Fig. I. But in the other three genera particles are carried forward along the tips from filament to filament at the region marked $x$ (indicated approximately only in Vermetus).

Passing to a more detailed examination of the individual filaments, in Buccinum (A) there are well-developed frontal, lateral and abfrontal cilia. Between the regions occupied by the last two is a wide area which is sparsely ciliated (as noted in living material but never revealed in sections). This region is chiefly notable for the presence of many large mucous glands $(m)$ and the irregular nature of the epithelium, in sharp contrast to its regular arrangement in the other ciliated regions. Dakin (I9I2), who studied sections cut parallel to the longitudinal axis of the filaments, speaks of the epithelium of the gill leaflet (the frontal region), the area of ciliated cells (the lateral region) and the area of glandular cells. His sections did not pass through the abfrontal region. Within the cavity of the filament are many blood corpuscles and much coagulated blood plasma, notably in the "glandular" region, which is presumably concerned with respiration and also with the entangling, in mucus, of any particles which are carried between the filaments in the current created by the lateral cilia. There are no mucous glands in the frontal or abfrontal regions, although they are abundant at the sides of the abfrontal epithelium. Muscular activity was observed in living tissue and there 


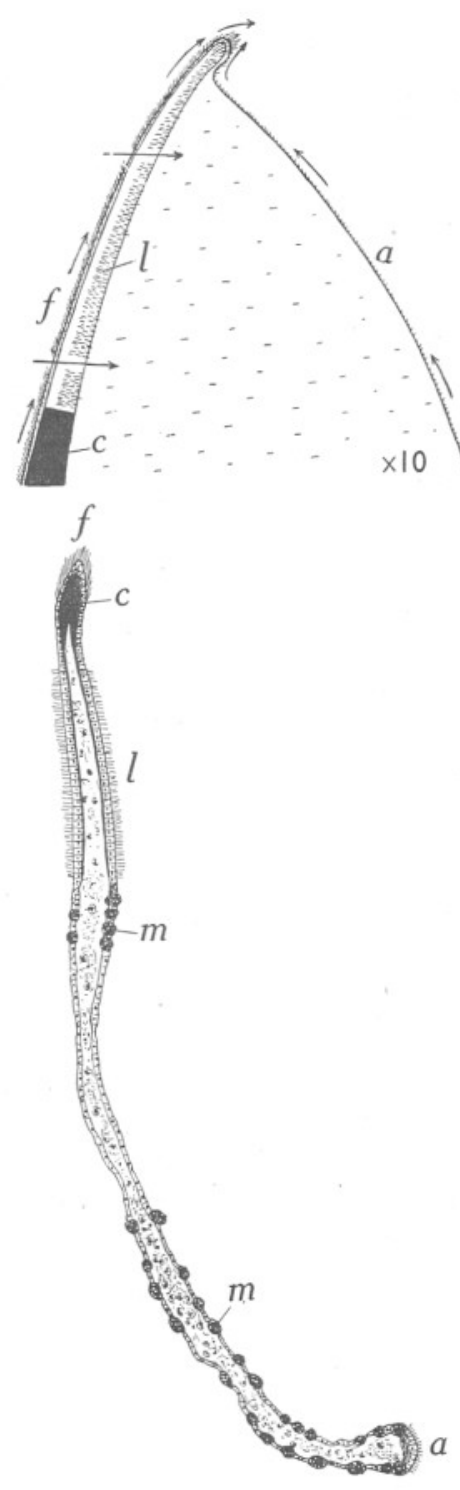

A

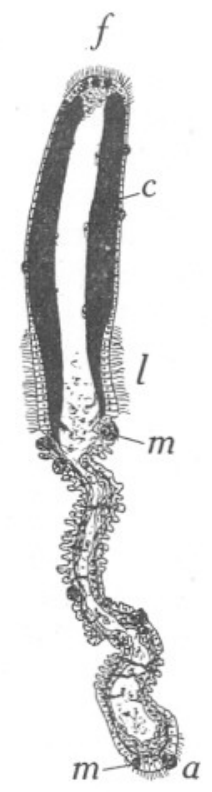

B
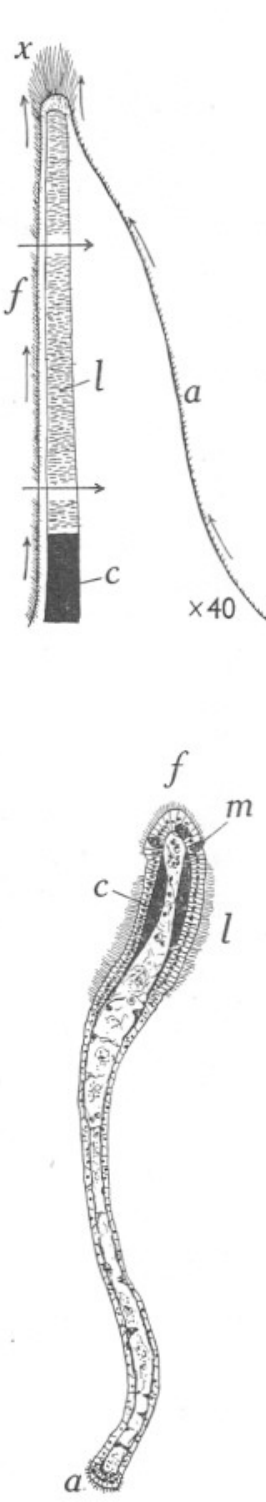

C

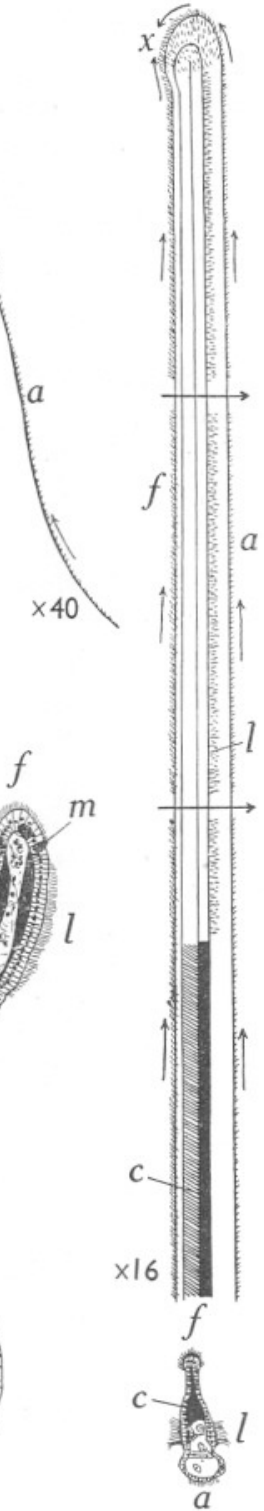

D

Fig. 6. Lateral view (above) and transverse section near base (below) of gill filaments of A, Buccinum undatum; B, Vermetus novae-hollandiae; C, Capulus ungaricus; D, Crepidula fornicata. Sections all $\times 55$; magnifications of whole filaments shown in figure. $a, a b-$ frontal cilia; $c$, chitinous supporting rods; $f$, frontal cilia; $l$, lateral cilia; $m$, mucous gland cells; $x$, region of anteriorly directed current at tips of filaments. 
are indications of muscle in the section, notably at the base of the abfrontal epithelium.

In Vermetus (в) the chitinous rods are exceptionally thick and broad and the area occupied by the lateral cilia is reduced and confined to the abfrontal third of the region supported by these rods. Mucous glands occur in all regions except in the epithelium which bears the lateral cilia. Their presence in both frontal and abfrontal epithelia indicates that their secretion assists in the entanglement of food particles in these regions. As already noted the filament has great powers of contraction, made possible by the presence, in the "glandular" and abfrontal regions, of longitudinal and transverse fibres and also others running across the central cavity. The wrinkled condition of the section indicates the effect of the contraction of the second and third of these sets of muscles.

In Capulus (c) conditions, in transverse section, approximate more to those in Buccinum, but mucous glands are here confined to the frontal region. It may be assumed, therefore, that collection of food particles by the frontal region is so efficient that few pass between the filaments, as they presumably do in the other two species. Muscle occurs, but not to the same extent as in the other two, although muscular movements were observed when living filaments were examined. An important feature is the great length of the terminal cilia, which exceed $100 \mu$.

Finally in Crepidula (D), where the filament is no longer triangular, mucous glands are rare, a condition clearly correlated with the presence of the endostyle (Fig. 3, EN), a mucus-producing organ which has been described in detail by Orton (I9I2, I9I4). The lateral cilia here lie nearer to the abfrontal region and beyond the region of the chitinous rods. There is little indication of muscle either in the behaviour of the living filaments or in sections. The tips of the filaments are flattened somewhat laterally, as shown in Fig. 6, but much more so dorso-ventrally, as described and figured by Orton (I9I2, Fig. 3). The filaments of Crepidula have clearly been modified to a much greater extent than those of Vermetus or Capulus.

The change in shape of the gill filaments from triangular to linear has had the important effect of increasing the extent of the region carrying lateral cilia-and so increasing the water current created in the mantle cavity-and also the extent of frontal and abfrontal regions, thereby augmenting the collecting surface. The accompanying reduction in the middle, or "glandular", region represents a reduction in the respiring surface. This is to some extent made good by the increased length of the gill (though not so in Crepidula) but, owing to the sedentary habits of these ciliary feeding Prosobranchia, the need for respiration will be distinctly less than that in actively moving genera, such as Buccinum. There is a tendency also for a relative increase in thickness of the chitinous supporting rods, necessary owing to the increased length of the filaments. The change in the distribution of the mucous glands may also be correlated in all three genera with feeding on fine particles, culminating in 
Crepidula with the acquisition of an endostyle and the loss of mucous glands on the filaments. The change in the beat of the terminal cilia has already been noted.

It has thus been possible for the purely respiring gill filament of Buccinum and similar Prosobranchia to be converted into an organ of food collection by essentially minor modifications, representing the conversion of ciliated rejection tracts into food-collecting tracts. The process, incidentally, indicates the manner in which the gill of the Filibranchia and Eulamellibranchia probably evolved (starting from a paired aspidobranch gill and not from the unpaired pectinibranch gill here considered). The most important differences in these groups are the folding back of the filaments, their increased cohesion by means of interlamellar and interfilamentary junctions of various kinds, and the appearance of latero-frontal cilia. The latter, which appear to be universally present in these two groups, although very small in more primitive Filibranchia such as Glycymeris and Arca (Atkins, 1936), probably developed owing to the need for a straining mechanism, in the absence of which the narrow spaces leading to the suprabranchial cavity in these complex gills would become blocked. There is clearly no such need in the unfolded and unattached gill filaments of these Prosobranchia.

\section{DisCUSSION}

The mode of feeding in the three families here discussed, the Vermetidae, Calyptraeidae and Capulidae, is in essentials the same, and undoubtedly represents a modification of ciliary mechanisms originally concerned with the rejection of sediment from the mantle cavity. There appears to be no reason for postulating a common origin for these families; the Vermetidae are admittedly widely removed from the other two, and they, though often grouped together (e.g. by Thiele (1925) in the Calyptraeacea), have many significant differences, their more superficial resemblances being very possibly the result of convergence due to similar modes of life and not of common origin. Lebour (1937) has recently shown that the larvae of Capulus possess an echinospira shell indicating relationship to the Lamellarioidea.

Modification of the ciliary mechanisms and associated changes are always correlated with complete or effective loss of the power of movement and with life in comparatively clear water. Loss of movement has involved the necessity of drawing food to the animal by means of ciliary currents (and by the unique method of mucous strings in Vermetus gigas), and this is possible only if the animal lives in water reasonably free from sediment which would clog the feeding tracts. Thus the Vermetidae live cemented to rocks and the Calyptraeidae and Capulus are frequently attached to the shells of Lamellibranchia, such as Ostrea or Pecten, or to stones, and so raised above the bottom deposits. Those living on Lamellibranchs will profit by the currents they create. 
The necessity for providing powerful feeding currents and extensive collecting surfaces has been met by the elongation of the original broadly triangular gill filaments and by the greater extent of the entire gill. But there has been no change in the direction of the ciliary currents except for the anteriorly directed current along the tips of the filaments, a current which corresponds in function to those present in the food grooves along the free edges of the demibranchs in the Lamellibranchia. In the Calyptraeidae food collection has been further assisted by the appearance of an endostyle. In all genera current B, essentially unmodified, assists current $\mathrm{C}$ in the collection of food-a ciliated tract on the floor of the mantle cavity carrying food finally towards the mouth-while in all but the Vermetidae current A, by modification of its direction, also assists in this process.

The invariable absence of a hypobranchial gland, so very well developed in typical Prosobranchia, is correlated with the increased size of the gill, the filaments of which extend to the right side of the mantle cavity. Moreover, being an essential part of the original cleansing and rejection mechanism, as postulated in the case of Aporrhais (Yonge, 1937), it is no longer necessary.

The radula and jaws have been retained but are modified in function. Peile (1937) has described the conspicuous absence of wear in the teeth of the radula of all of these animals and concludes, "we may sum up the function of the radula as grasping, not rasping". Thus, although the gills have become modified in the direction of those of the Lamellibranchia and give some indication of the manner in which they have evolved, the actual taking in of food at the mouth consists of the grasping, by radula and jaws, of mucusladen masses which are passed back into the oesophagus by the conveying action of the radula. Nothing in the nature of a selective mechanism, represented in the Lamellibranchia by the labial palps, the complex ciliated tracts on which rigorously control the passage of material to the mouth, has been evolved in these Gastropoda.

The evolution of ciliary feeding has taken significantly different directions in the three families. In the Vermetidae it is associated with a retention, and remarkable enlargement, of the pedal gland, which provides mucus for the consolidation of food particles in species such as Vermetus novae-hollandiae, while in $V$. gigas a still greater enlargement of this gland permits direct feeding by its secretion. In the Calyptraeidae the elaboration of ciliary feeding mechanisms has been taken to the highest degree of perfection recorded in the Prosobranchia: by the enlargement of the mantle cavity and of the gill, modification of the filaments, possession of an endostyle and conversion of all three rejection tracts into food streams. Finally in the Capulidae an increase in the size of the gill has been made possible by its oblique position in the mantle cavity; but the most characteristic feature is the remarkable grooved proboscis, the further evolution of which has resulted in the parasitic habit found in Thyca. The trends of evolutionary change in all three families may suitably be indicated diagrammatically as follows: 


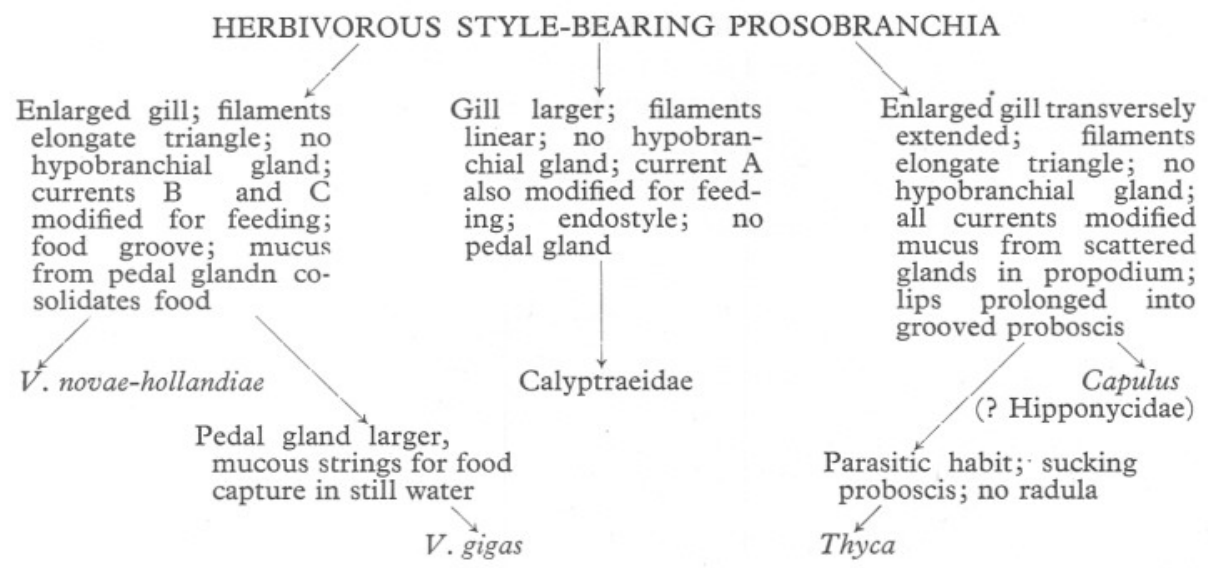

\section{SUMMARY}

I. Ciliary currents concerned with rejection of sediment from the mantle cavity of pectinibranch Prosobranchia consist of A, currents carrying heavier particles to the inhalent opening; $\mathrm{B}$, currents carrying medium particles across the floor of the mantle cavity; C, currents carrying fine particles over and between the gill filaments for later consolidation by the mucus from the hypobranchial gland. Material in currents B and C is rejected from the exhalent opening.

2. The feeding currents in ciliary feeding Prosobranchia represent modifications of these rejection currents.

3. In Vermetus novae-hollandiae currents B and C only are modified, material being passed to the mouth region, where it is mixed with mucus from the large pedal gland, by way of a food groove.

4. In Crepidula fornicata and other Calyptraeidae all currents are modified for feeding and there is an endostyle for mucus secretion.

5. In Capulus ungaricus all currents are modified, food collecting on the upper surface of the propodium, where mucus is secreted and mucus-laden masses are passed to the mouth by way of the grooved proboscis.

6. In ciliary feeding species the gill is enlarged and the filaments tend to become longer and linear. This results in the production of an increased feeding current and collecting surface and the loss of the hypobranchial gland. Cilia at the tips of the filaments beat anteriorly. The distribution of mucous glands on the filaments can be correlated with the change in their function.

7. The possible mode of evolution of the lamellibranch gill is discussed in the light of these findings.

8. In the ciliary feeding Prosobranchia radula and jaws are retained for the grasping of the mucus-laden food masses; nothing equivalent to the labial palps of Lamellibranchia is present. 
9. Evolution of ciliary feeding has probably been independently achieved in the three families considered. In the Vermetidae further development of the pedal gland enables direct mucus feeding, as in Vermetus gigas; in the Capulidae evolution culminates in a parasitic habit as in Thyca; only in the Calyptraeidae, where ciliary feeding mechanisms are most highly organized, do all genera and species appear exclusively to be ciliary feeders.

\section{REFERENCES}

Atkıns, D., I936. On the ciliary mechanisms and interrelationships of Lamellibranchs. Part I. Quart. Fourn. Micr. Sci., Vol. Lxxix, pp. I8I-308.

Boettger, C. R., I930. Studien zur Physiologie der Nahrungsaufnahme festgewachsener Schnecken. Die Ernährung der Wurmschnecke Vermetus. Biol. Zbl., Bd. L, pp. 58I-97.

BRockMeIER, H., I898. Süsswasserschnecken als Planktonfischer. Plöner Forschungsber., Bd. vI, p. I65.

DAKIN, W. J., I9I2. Buccinum. L.M.B.C. Mem., No. xx.

Hulbert, G. C. E. B. \& Yonge, C. M., I937. A possible function of the osphradium in the Gastropoda. Nature, Vol. cxxxIx, p. 840.

Kleinsteuber, H., I9I3. Die Anatomie von Trochita, Calyptraea und fanacus. Zool. Fahrb. Suppl. 13, Fauna chilensis, Bd. IV, pp. 385-476.

KoeHLER, R. \& VANEY, C., I9I2. Nouvelles formes de Gastéropodes ectoparasites. Bull. Sci. France Belg., T. XLVI, pp. I9I-2I7.

Lebour, M. V., I937. The eggs and larvae of the British Prosobranchs with special reference to those living in the plankton. Fourn. Mar. Biol. Assoc., Vol. xxir, pp. 105-66.

OrTON, J. H., I9I2. The mode of feeding in Crepidula, with an account of the currentproducing mechanism in the mantle cavity. Fourn. Mar. Biol. Assoc., Vol. IX, pp. $444-78$.

- I9I4. On ciliary mechanisms in Brachiopods and some Polychaetes, with a comparison of the ciliary mechanisms on the gills of molluscs. Fourn. Mar. Biol. Assoc., Vol. x, pp. 283-3Ir.

Peile, A. J., I937. Some Radula problems. Fourn. Conch., Vol. xx, pp. 292-304.

Schepman, M. M. \& Nierstrasz, H. F., 1909. Parasitische Prosobranchier der Siboga-Expedition. Siboga-Expeditie, Mon. XLIX ${ }^{2}$.

Thiele, J., I925. Prosobranchia. Handbuch der Zoologie, Kükenthal und Krumbach, Bd. v, pp. 40-94.

YoNGE, C. M., I926. Ciliary feeding mechanisms in the Thecosomatous Pteropoda. Fourn. Linn. Soc. Lond., Zool., Vol. XxxvI, pp. 4I7-29.

- 1932. Notes on feeding and digestion in Pterocera and Vermetus, with a discussion on the occurrence of the crystalline style in the Gastropoda. Sci. Rpts. G. Barrier Reef Exped., Brit. Mus. (Nat. Hist.), Vol. I, pp. 259-8I.

- 1937. The biology of Aporrhais pes-pelecani (L.) and A. serresiana (Mich.). fourn. Mar. Biol. Assoc., Vol. xxI, pp. 687-704.

Note. Since this paper went to press I have had the pleasure of seeing the manuscript of a forthcoming paper by $\mathrm{Mr}$ A. Graham on ciliary feeding in Turritella communis. Essentially the same mechanisms are involved as in the species here considered, but there are most interesting modifications due to the fact that this animal is adapted for ciliary feeding in a muddy environment. 